JSAP: Journal Syariah and Accounting Public

ISSN: 2622-3538

Available Online at https://journal.umgo.ac.id/index.php/JSAP/index

Vol. 3, No. 2 Desember 2020

DOI: $10.31314 /$ jsap.3.2.51-58.2020

\title{
TRANSPARANSI PENGUNAAN DANA DESA DALAM PEMBANGUNAN MAHYANI DI DESA LELATO KECAMATAN SUMALATA KABUPATEN GORONTALO UTARA
}

\author{
Srihandayani Suprapto ${ }^{1}$, Maharani Ayuba ${ }^{2}$ \\ 1,2.Program Studi Administrasi Publik Fakultas Ilmu Sosial Universitas Muhammadiyah \\ Gorontalo, Indonesia \\ Email; srihandayani suparapto@umgo.ac.id
}

Info Artikel: Diterima: 13 Oktober 2020, Disetujui: 23 November 2020, Publish 15 Desember 2020

\begin{abstract}
:
This research aims to determine the transparency of the use of village funds in Mahyani development in Lelato Village, Sumalata District, North Gorontalo District. The research method used is a qualitative approach with descriptive research type. The results showed that the transparency of the use of village funds in mahyani development was not in accordance with what was expected. Of the three indicators to measure the level of transparency, there is one indicator that has worked well, namely the indicator of the ease of obtaining information. Meanwhile, two indicators that have not been going well are openness, where there is still a need for transparency on the mahyani development mechanism which often raises public perceptions. Then on the indicators of regulations and procedures, there is still a need for socialization about regulations related to mahyani development so that it does not cause a decrease in public trust in the village government.
\end{abstract}

Keywords: Transparency, Village Fund, Mahyani Development

\begin{abstract}
Abstrak:
Penelitian bertujuan untuk mengetahui Transparansi Penggunaan Dana Desa dalam Pembangunan Mahyani di Desa Lelato Kecamatan Sumalata Kabupaten Gorontalo Utara. Metode penelitian yang digunakan adalah pendekatan kualitatif dengan jenis penelitian deskriptif. Hasil penelitian didapatkan bahwa transparansi penggunaan dana desa dalam pembangunan mahyani belum sesuai dengan apa yang diharapkan. Dari tiga indikator untuk mengukur tingkat transparansi, terdapat satu indikator yang sudah berjalan dengan dengan baik yakni indikator kemudahan memperoleh informasi. Sementara untuk dua indikator yang belum berjalan dengan baik adalah keterbukaan, dimana masih perlu adanya transparansi terhadap mekanisme pembangunan mahyani yang sering menimbulkan persepsi masyarakat. Kemudian pada indikator peraturan dan prosedur masih perlu adanya sosialisasi tentang regulasi terkait dengan pembangunan mahyani sehingga tidak menimbulkan berkurangnya kepercayaan masyarakat terhadap pemerintah desa.
\end{abstract}

Kata kunci : Transparansi, Dana Desa, Pembangunan Mahyani

\begin{aligned} & PENDAHULUAN batas wilayah tertentu yang memiliki \\ & Secara umum Desa merupakan $\begin{array}{l}\text { kewenangan untuk mengatur dan mengurus } \\ \text { segala kepentingan masyarakatnya } \\ \text { kesatuan masyarakat yang memiliki batas- } \\ \text { berdasarkan hukum dan norma-norma serta }\end{array} \\ &$\hline\end{aligned}

JSAP: Journal Syariah and Accounting Public, Vol. 3, No. 2 Desember $2020 \mid 51$ 
adat istiadat yang dipempin oleh kepala desa yang di akui oleh Negara Kesatuan Republk Indonesia (NKRI). Menutut UndangUndang No 6 tahun 2014 Desa adalah kesatuan masyarakat hukum yang memiliki batas wilayah tertentu yang memiliki wewenang untuk mengatur dan mengurus segala kepentingan masyarakat baik urusan penyelenggaraan pemerintahan, pembangunan dan berdasarkan prakarsa masyarakat, hak asal ususl yang di hormati dan diakui oleh Negara. Pada masa orde baru sistem pemerintahan Indonesia dari sentralisasi menjadi desentralisasi. Sistem sentralisasi adalah sistem pemerintahannya terpusat pada pemerintah pusat dalam menentukan arah pemabanguannya. Sehingga sistem sentralisasi ini kurang efektif karena kurang meratanya pembangunan yang ada di Indonesia. Sementara itu sistem desentralisasi merupakan sistem yang anggap efektif karena peerintah pusat memberikan wewenangnya kepada pemerintah daerah untuk meningkatkan pembangunan serta fungsi-fungsi pelayanan pemeritahan kepada masyarakat. Hal inilah menjadikan desa menjadi objek penting bagi pembangunan di Indonesia.

Pemerintahan desa adalah ruang lingkup terkecil dalam pembangunan pemerintahan Republik Indonesia. namun, Pemerintahan desa juga memiliki peranan penting dalam pembangunan. sehingganya pembangunan yang ada di setiap desa bisa berjalan secara maksimal, maka tujuan dari pemerintah pusat untuk memberikan wewenang untuk pemerataan kesejahteraan dan pembangunan yang merata bisa terwujud. Oleh sebab itu, kondisi yang ada di beberapa daerah di Indonesia yang belum mendapat perhatian yang sesuai dengan harapan pemerintah pusat. maka, peran dari pemerintah daerah sangat dibutuhkan untuk meningkatkan otonomi daerah oleh karena itu desa juga memiliki hak untuk membuat aturan-aturan dalam kehidupan desa sebelum di jadikan sebagai peraturan daerah. Sehingganya Peran dari pemerintah daerah diharapkan dapat memberikan dampak positif serta mampu membimbing dan mengawasi setiap kegiatan pemerintah desa Program maupun kebijakan yang dilakukan oleh pemerintah desa terhadap kewenangan yang diberikan dapat dipertanggungjawabkan oleh kepaladesa maupun aparatur desa kepada masyarakat pada umumnya maupun kepada pemerintah daerah/pusat.

Pemerintah desa diwajibkan untuk bisa mengelola serta mengatur segala urusan pemerintahannya. Hal tersebut dimulsi dari perencanaan, pelaksaanan, penatausahaan, pertanggungjawaban dan pemanfaatannya dari program-program yang dikelola oleh pemerintah desa. maka, Kepala desa maupun perangkat desa mampu dan wajib memahami Tugas Pokok dan Fungsi (Tupoksi) demi meningkatkan kinerja dan berperan akti terhadap program dari pemerintah desa sehingga akan berdampak baik. Untuk program-program yang telah direncanakan oleh pemerintah desa bisa berjalan dengan efektif dan efisien maka pemerintah desa saat ini menjadi salah satu objek pertama dan menjdi pusat perhatian pengawasan masyarakat.

Transparansi merupakan keterbukaan bagi pengawasan. Sedangkan yang dimaksud dengan informasi yakni segala sesuatu yang berhubungan informasi terhadap setiap aspek kebijakan pemerintahan yang dapat diakses oleh semua kalangan dalam hal ini dala masyarakat luas/publik. Keterbukaan informasi ini diharapkan dapat memberikan pelayanan terhadap peran politik yang sehat dan penuh toleransi, serta mampu 
memberikan informasi kebijakan pemerintahan yang dibuat beradasarkan pelayanan publik.

Menurut, Krina (2003:13) beliau mengatakan bahwa transparansi adalah sebuah prinsip yang menjamin akses atau kebebasan bagi setiap orang untuk mendapat kemudahan untuk memperoleh informasi tentang penyelenggaraan pemerintahan, seperti informasi tentang kebijakan proses pembuatan dan pelaksanaanya serta hasil-hasil yang akan di capai.

Menurut Mardiasmo (2004:30), dalam bukunya beliau mendefinisikan transparansi merupakan keterbukaan (opennsess) pemerintah dalam memberikan informasi terkait dengan aktivitas pengelolaan sumber daya publik kterhadap bergai pihak-pihak yang membutuhkan informasi.

Menurut Hari Sabarno (2007:38) mendefinisikan transparansi merupakan salah satu aspek yang mendasar bagi public untuk terwujudnya penyelenggaraan pemerintahan yang baik. sistem pemerintahannya terdiri dari adanya keterbukaan, keterlibatan, serta kemudahan akses bagi masyarakat terhadap proses penyelenggaraan pemerintah. Kemudahan dalam memperoleh informasi penyelenggaran pemerintahan memberikan dampak bagi publik untuk mewujudkan indikatornya.

Makna dari transparansi dalam penyelenggaraan pemerintahan daerah dapat dilihat dalam dua hal yakni :

1. Salah satu wujud pertanggung jawaban pemerintah kepada rakyat, dan

2. Upaya peningkatan manajemen pengelolaan dan penyelenggaraan pemerintahan yang baik dan mengurangi kesempatan praktek kolusi, korupsi dan nepotisme (KKN).
Agus Dwiyanto

(2006:80)

mendefinisikan transparansi adalah sebagai salah satu penyediaan informasi public tentang pemerintahan dan kemudahan untuk memperoleh informasi-informasi yang akurat, terpecaya serta memadai sehingga dapat di artikan bahwa transparansi tidak hanya untuk sekedar menyediakan informasi tentang penyelenggaraan pemerintahan, akan tetapi harus disertai dengan kemudahan bagi masyarakat dalam memperoleh informasi-informasi yang berguna bagi public yang dapat berdampak positif bagi pemerintah dan masyarakat.

Kemudian untuk mengukur tingkat transparansi penyelenggaraan pemerintahan, Agus dwiyanto mengemukakan bahwa ada tiga indikator untuk mengukur tingkat transparansi yaitu :

1) untuk mengukur tingkat keterbukaan proses penyelenggaraan pelayanan public harus terdiri dari Persyaratan, biaya, waktu dan prosedur yang ditempuh harus dipublikasikan kepada masyarakat secara terbuka dan mudah diketahui serta berusaha menjelaskan alasannya apabila ada pertanyaan-pertanyaan piblik.

2) Peraturan dan prosedur terhadap pelayanan public dapat dipahami oleh pengguna dan stakeholders lainnya. Aturan dan prosedur bersifat sederhana, langsung dan mudah diterapkan)

3) kemudahan memperoleh informasi harus bebas didapat dan siap tersedia

Dari uraian di atas, prinsip transparansi pemerintahan paling dapat diukur dengan tiga indikator yakni adanya :

a) Sistem keterbukaan yang baik dan standarisasi yang jelas serta mudah 
dipahami proses-proses dari penyelenggaraan pemerintahan.

b) mekanisme yang memfasilitasi pertanyaan-pertanyaan publik tentang proses-proses dalam penyelenggaraan pemerintahan.

c) mekanisme pelaporan baik penyebaran informasi penyimpangan tindakan aparat publik di dalam kegiatan penyelenggaraan pemerintahan.

Pengelolaan Keuangan Desa merupakan suatu proses dari keseluruhan kegiatan penyelenggaraan pemerintahan desa yang dimulai dari proses perencanaan kegiatan, pelaksanaan penyelenggaraan pemerintahan, penatausahaan, pelaporan serta pertanggungjawaban keuangan desa. Rencana Kerja Pemerintah Desa (RKPDes) yang merupakan penjabaran dari Rencana Pembangunan Jangka Menengah Desa (RPMDes) untuk jangka waktu 1 (satu) tahun.

Sesuai dengan Permendagri 20 Tahun 2018 tentang Pengelolaan Keuangan Desa bagian 2 Asas Pengelolaan Keuangan Desa pasal 2 yakni :

1) Keuangan Desa dikelola sesuai peraturan dan harus bersifat asas transparan, akuntabel, partisipatif serta dilakukan dengan tertib dan disiplin anggaran.

2) APBDes merupakan dasar pengelolaan keuangan Desa dalam masa 1 (Satu) tahun anggaran mulai tanggal 1 Januari sampai dengan tanggal 31 Desamber.

Dalam Penyelenggaran kewenangan Desa harus sesuai dengan hak asal usul dan kewenangan lokal berskala Desa yang didanai oleh Anggaran Pendapatan dan Belanja Desa (APBDes). Namun Penyelenggaran lokal berskala Desa juga selain didanai oleh APBDes, juga di danai oleh Anggaran Pendapatan dan Belanja Negara (APBN) dan Anggaran Pendapatan dan Belanja Daerah (ABPD). Untuk itu Penyelenggaraan kewenangan Desa yang ditugaskan oleh Pemerintah yang didanai oleh Anggaran Pendapatan dan Belanja Negara (APBN). Kemudian Dana anggaran pendapatan dan belanja Negara dialokasikan pada bagian anggaran kementrian/lembaga dan disalurkan melalui satuan kerja perangkat daerah kabupaten/kota.

Dana desa merupakan dana yang bersumber/berasal dari Angaran Pendapatan Belanja Negara (APBN) yang diperuntukkan bagi desa yang ditransfer melalui anggaran belanja daerah kabupaten/kota (APBD). Dana tersebut harus digunakan untuk membiayai penyelenggaraan pemerintahan, pelaksanaan pembangunan, pembinaan kemasyarakatan dan pemberdayaan masyarakat desa. Sedangkan alokasi dana desa merupakan bagian dari dana perimbagan keuangan pusat dan daerah yang diterima oleh daerah/kabupaten untuk desa paling sedikit 10 persen yang pembagiannya untuk desa secara proporsional dalam anggaran pendapatan dan belanja daerah setelah dikurang dana alokasi khusus. Maka intinya, alokasi dana desa adalah bagian keuangan desa yang diperoleh dari hasil bagi hasil pajak daerah dan bagian dari dana perimbangan keuangan pusat dan daerah yang diterima oleh kabupaten/kota untuk desa yang dibagikan secara proporsional.

Tujuan penelitian ini adalah untuk mengetahui bagaimana Transparansi Penggunaan Dana Desa dalam Pembangunan Mahyani di Desa Lelato Kecamatan Sumalata Kabupaten Gorontalo Utara. 


\section{METODE PENELITIAN}

Pendekatan yang digunakan penulis pada penelitian ini adalah penelitian kualitatif. Menurut poerwandari (2007) mengungkapkan bahwa penelitian kualitatif menghasilkan dan mengelolah data yang sifatnya deskriptif, seperti transkip wawancara, catatan, lapangan, gambar, foto, rekaman video, dan lain sebagainya.

Menurut Marshal C dan Rossman G.B, 1995. Penelitian kualitatif didefinisikan sebagai suatu proses yang mencoba untuk mendapatkan pemahaman yang lebih baik mengenai kompleksitas yang ada dalam interaksi manusia.

Penelitian ini telah dilaksanakan di Desa Lelato, Kecamatan Sumalata, Kabupaten Gorontalo Utara sejak tanggal 5 Mei sampai 5 April 2021. Pemerintah Desa Lelato dipilih dikarenakan, Merupakan salah satu Desa berkembang yang ada diwilayah Sumalata bagian barat.

Penelitian ini menggunakan sumber data primer yaitu melalui wawancara dengan informan dan melakukan observasi lapangan dan sumber data sekunder yaitu berupa catatan yang di peroleh dari lapangan. Metode pengumpulan data menggunakan wawancara, observasi dan dokumentasi. Analisis data menggunakan teknik dari Miles and Huberman (dalam Sugiyono, 2012).

\section{HASIL DAN PEMBAHASAN}

Berdasarkan hasil wawancara dengan informan menujukan bahwa beberapa informan memberikan tanggapan yang positif dan ada juga yang memberikan tanggapan negative terhadap pertanyaan yang penulis ajukan berkaitan dengan Transparansi Penggunaan Dana Desa dalam Pembangunan Mahyani di Desa Lelato Kecamatan Sumalata Kabupaten Gorontalo Utara. Namun melihat pengamatan dan kondisi lapangan yang dilakukan peneliti menandakan bahwa tingkat Transparansi Penggunaan Dana Desa yang ada di Desa lelato masih perlu dilakukan perbaikan sehingga masyarakatnya tidak akan bertanya-tanya lagi. Selain itu bukti fisik yang tentunya masih perlu ada peningkatan baik itu pengecetan harus menjadi perhatian pemerintah desa lelato sebab ini merupakan salah satu keluhan masyarakatnya.

Penelitian ini bertujuan untuk mengetahui tingkat Transparansi Penggunaan Dana Desa dalam Pembangunan Mahyani di Desa Lelato Kecamatan Sumalata Kabupaten Gorontalo Utara, yang berdasarkan kepada teori yang dikembangakan oleh Agus Dwiyanto. Bahwa untuk mengukur tingkat transparansi penyelenggaraan pemerintahan dapat di ukur dengan tiga indikator yaitu, Keterbukaan, Peraturan dan Prosedur serta Kemudahan memperoleh informasi. Hasil dan analisis kualitatif terhadap masingmasing indikator dapat di uraikan sebagai berikut :

1. Keterbukaan

Pada penelitian, keterbukaan merupakan hal yang sangat diperlukan dalam proses penyelenggaraan pelayanan publik. Keterbukaan ini mencakup pada persyaratan, biaya, waktu dan prosedur yang ditempuh harus dipublikasikan secara terbuka dan mudah diketahui serta berusaha menjelaskan alasannya.

Berdasarkan hasil penelitian melalui informan yang telah dlakukan kepada 
beberapa informal yang terdiri dari Sekretaris Desa, Stap BPD, Kasei Kesejahteraan dan Pelayanan, Kaur Umum, Kepala Dusun Beringin Jaya, Kasie Pemerintahan dan Operator Desa Lelato Kecamatan Sumalata Kabupaten Gorontalo Utara terkait dengan indikator yang pertama yakni Keterbukan tentang Transparansi Penggunaan Dana Desa dalam Pembangunan Mahyani di Desa Lelato Kecamatan Sumalata Kabupaten Gorontalo Utara, maka Peneliti menyimpulkan bahwa kegiatan keterbukaan yang ada di Desa Lelato belum berjalan sesuai dengan apa yang diharapkan, dimana pemerintah desa dalam hal transparansi belum sepenuhnya melakukan keterbukaan. Meski pemerintah desa selalu melakukan musyawarah desa yang dipimpin langsung oleh pimpinan sidang dalam hal ini adalah Ketua BPD. Namun ada beberapa masyarakat yang menyatakan bahwa keterbukaan pemerintah desa belum sepenuhnya terlaksana dengan baik sebab masih ada persepsi masyarakat yang berbeda dengan apa yang disampaikan oleh pemerintah desa.

\section{Peraturan dan Prosedur}

Setiap kebijakan dalam pengambilan keputusan hendaknya sesuai dengan peraturan dan prosedurnya masing-masing, sehingga tidak akan menimbulkan masalah yang akan merugikan berbagai pihak. Merujuk pada seberapa mudah peraturan dan prosedur pelayanan dapat dipahami oleh pengguna dan stekeholdersnya yang lain, maka aturan dan prosedur tersebut bersifat "simple, straightforward and easy to apply" ( Sederhana, langsung dan mudah diterapkan) untuk mengurangi perbedaan dalam interpretasi.

Berdasarkan hasil wawancara dilakukan kepada beberapa informan yang terdiri dari Sekretaris Desa, Kasei Kesejahteraan dan Pelayanan, Kaur Umum,
Kasie Pemerintahan, Operator Desa, stap BPD, Tokoh Masyarakat dan masyarakat Desa Lelato Kecamatan Sumalata Kabupaten Gorontalo Utara terkait dengan Peraturan dan Prosedur Transparansi Penggunaan Dana Desa dalam Pembangunan Mahyani di Desa Lelato Kecamatan Sumalata Kabupaten Gorontalo Utara, maka peneliti dapat mengambil kesimpulan bahwa Peraturan dan Prosedur terkait pembangunan mahyani ini sudah sesuai namun masih perlu ada perbaikan kedepannya sehingga tidak menimbulkan persepsi masyarakat serta keterlambatan proses finishingnya tidak terhambat lagi. Memang fungsi BPD adalah Pengawasan namun hal yang seperti ini juga harus diperhatikan agar kedepan tidak akan menimbulkan kesalahpahaman antara Pemerintah Desa Lelato dan Masyarakatnya.

3. Kemudahan Memperoleh Informasi

Pada indikator yang ketiga ini, kemudahan memperoleh informasi mengenai berbagai aspek penyelenggaraan pelayanan publik, informasi tersebut bebas didapat dan siap tersedia (freely dan readily available).

Dengan melihat uraian di atas, prinsip transparansi pemerintahan paling tidak dapat diukur melalui sejumlah indikator sebagai berikut:

a. Adanya sistem keterbukaan dan standarisasi yang jelas dan mudah dipahami dari semua proses-proses penyelenggaraan pemerintahan.

b. Adanya mekanisme yang memfasilitasi pertanyaan-pertanyaan publik tentang proses-proses dalam penyelenggaraan pemerintahan.

c. Adanya mekanisme pelaporan maupun penyebaran informasi penyimpangan tindakan aparat publik 
di dalam kegiatan penyelenggaraan pemerintahan.

Berdasarkan hasil wawancara yang telah dilakukan kepada para informan yang terdiri dari Sekretaris Desa, Kasie Kesejahteraan dan Pelayanan, Stap BPD, Tokoh Masyarakat dan Masyarakat yang ada di Desa Lelato Kecamatan Sumalata Kabupaten Gorontalo Utara terkait dengan Kemudahan memperoleh informasi tentang Transparansi Penggunaan Dana Desa dalam Pembangunan Mahyani di Desa Lelato Kecamatan Sumalata Kabupaten Gorontalo Utara, maka peneliti berpendapat bahwa Selama ini pemerintah desa lelato sudah transparan dalam penggunaa Dana Desa yang di peruntukan untuk pembangunan mahyani yang di desa Lelato Kecamatan Sumalata Kabupaten Gorontalo Utara.

\section{KESIMPULAN}

Berdasarkan hasil penelitian dan pembahasan, maka dapat disimpulkan bahwa Transparansi Penggunaan Dana Desa dalam Pembangunan Mahyani di Desa Lelato Kecamatan Sumalata Kabupaten Gorontalo Utara belum berjalan dengan baik. Dari tiga indikator untuk mengukur tingkat transparansi dapat dijabarkan bahwa dari tiga indikator untuk mengukur tingkat transparansi, terdapat satu indikator yang sudah berjalan dengan dengan baik yakni indikator kemudahan memperoleh informasi. Sementara untuk dua indikator yang belum berjalan dengan baik adalah keterbukaan, dimana masih perlu adanya transparansi terhadap mekanisme pembangunan mahyani yang sering menimbulkan persepsi masyarakat. Kemudian pada indikator peraturan dan prosedur masih perlu adanya sosialisasi tentang regulasi terkait dengan pembangunan mahyani sehingga tidak menimbulkan persepsi masyarakat serta berkurangnya kepercayaan masyarakat terhadap pemerintah desa.

\section{SARAN}

Berdasarkan kesimpulan diatas, maka ada beberapa hal dapat di sarankan yaitu :

1. Perlunya dilakukan Sosialisasi terkait dengan regulasi penyelenggaraan pemerintah desa dalam hal ini adalah tahapan-tahapan dalam penggunaan dana desa khususnya dalam Pembangunan Mahyani

2. Perlunya membangun Koordinasi kepada pihak-pihak tertentu (Pemerintah, BPD, LPM dan Masyarakat itu sendiri.

3. Perlu adanya perbaikan tentang mekanisme musyawarah terutama peserta rapat harus melibatkan masyarakat pada umumnya:

\section{REFERENSI}

Agus Dwiyanto (2006:80) transparansi sebagai penyediaan informasi tentang pemerintahan bagi publik dan dijaminnya kemudahan di dalam memperoleh informasi-informasi yang akurat dan memadai

Deri. 2017. "Peran Badan Permusyawaratan Desa (BPD) Dalam Pengawasan Pengelolaan APBDes Di Desa Senambah Kecamatan Muara Bengkal Kabupaten Kutai Timur." e-Journal IImu Pemerintahan 5(1): 121-32.

Emzir. (2010). Metodologi Penelitian Kualitatif: Analisis Data (Edisi Kesa). Jakarta:PT. Raja Grafindo Persada.

Fitra, Amanda Aidil. 2016. "Analisis Implementasi Pengelolaan Keuangan Desa Dalam Penggunaan Dan Pelaporan Dana Desa (Kasus: Desa Panggungharjo Kecamatan Sewon Kabupaten Bantul)." Universitas Gadjah Mada.

Fajri, Rahmi, and Endah Setyowati. 2015. "Akuntabilitas Pemerintah Desa Pada Pengelolaan Alokasi Dana Desa 
(ADD) (Studi Pada Kantor Desa Ketindan, Kecamatan Lawang, Kabupaten Malang)." Jurnal Administrasi Publik (JAP) 3(7): 10991104.

Ferina, Ika Sasti, Burhanuddin, and Herman Lubis. 2016. "Tinjauan Kesiapan Pemerintah Desa Dalam Implementasi Peraturan Menteri Dalam Negeri Nomor 113 Tahun 2014 Tentang Pengelolaan Keuangan Desa (Studi Kasus Pada Pemerintah Desa Di Kabupaten Ogan Ilir)." Jurnal manajemen dan bisnis 14(3): 321-36.

Hari Sabarno (2007:38) transparansi merupakan salah satu aspek mendasar bagi terwujudnya penyelenggaraan pemerintahan yang baik. Perwujudan tata pemerintahan yang baik mensyaratkan adanya keterbukaan, keterlibatan, dan kemudahan akses bagi masyarakat.

Hendi Sandi Putra. 2017. "Tata Kelola Pemerintahan Desa Dalam Mewujudkan Good Governance Dsi Desa Kalibelo Kabupaten Kediri." Jurnal Politik Muda 6(2): 110-19.

Howitt, D., \& Cramer, D. (2008). Introduction to research methods in psychology.

(Harlow, Ed.) (2nd edn). Essex: Pearson Education Limited.

Kartika Et Al, 2018“Akuntabilitas Pengelolaan Dana Desa Tahun 2016 di Desa Pemecutan Kaja" Jurnal, Universitas Gaja Mada

Krina (2003:13) transparansi sebagai prinsip yang menjamin akses atau kebebasan bagi setiap orang untuk memperoleh informasi tentang penyelenggaraan pemerintahan, yakni informasi tentang kebijakan proses pembuatan dan pelaksanaanya serta hasil-hasil yang dicapai.

Mardiasmo (2004:30), transparansi berarti keterbukaan (opennsess) pemerintah dalam memberikan informasi yang terkait dengan aktivitas pengelolaan seumber daya publik kepada pihakpihak yang membutuhkan informasi.

Marshal C dan Rossman G.B, 1995. Penelitian kualitatif

Miles and Huberman (dalam Sugiyono, 2012). Metode Penelitian

Pengumpulan Data.

Poerwandari (2007) Metode Kualitatif.

Sumber-Sumber Lain :

Undang-Undang No 6 tahun 2014

Permendagri 20 Tahun 2018 tentang pengelolaan Keuangan Desa. 